ROCZNIKI PEDAGOGICZNE

Tom 12(48), numer $4 \quad 2020$

DOI: https://doi.org/10.18290/rped20124-6

TOMASZ RÓŻAŃSKI

\title{
SAMOTNOŚĆ I OSAMOTNIENIE OSÓB STARSZYCH JAKO PROBLEM SPOŁECZNY I EDUKACYJNY
}

\begin{abstract}
WSTĘP
Zagadnieniom starości i samego człowieka starego poświęca się coraz więcej uwagi, co należy łączyć $\mathrm{w}$ dużej mierze $\mathrm{z}$ procesem starzenia się współczesnych społeczeństw (Fabiś, Wawrzyniak, Chabior, 2017; Kanios, 2018). Zjawisko to „ujawnia pilną potrzebę zarówno podejmowania, jak i promowania działań na rzecz populacji osób starszych, których wynikiem byłoby podniesienie jakości ich życia nie tylko przez tworzenie ram dobrze realizowanej opieki i wsparcia dla seniorów, lecz także przez propagowanie zdrowego, pomyślnego starzenia się na wielu płaszczyznach życia codziennego" (Fabiś, Wawrzyniak, Chabior, 2017, s. 9).

Okres starości, podobnie jak inne fazy życia, nie jest wolny od rozmaitych trosk i niepokojów egzystencjalnych. Mogą być one związane np. ze stratą bliskich osób, żałobą, wdowieństwem czy lękiem przed śmiercią. Zalicza się do nich problem samotności i osamotnienia (Fabiś, 2017b, s. 279-297). Jak stwierdza Emilia Kramkowska, „w przypadku ludzi starych samotność i osamotnienie to stany niezwykle silne, wywołane czy to stanem zdrowia i ograniczoną mobilnością seniora, czy to śmiercią współmałżonka lub innych bliskich osób, bądź społecznym, nieraz mało życzliwym odbiorem ich osoby" (Kramkowska, 2016, s. 41-42). Konsekwencją tego stanu rzeczy jest nierzadko cierpienie, lęk, poczucie krzywdy (Kramkowska, 2016, s. 41), jak również gniew i rozczarowanie (Rembowski, 1992, s. 40). Stąd problem samotności i osamotnienia ludzi starszych pociąga za sobą potrzebę podejmowania różnorakich działań w dziedzinie edukacji, profilaktyki oraz pomocy
\end{abstract}

Dr Tomasz RóżAŃSKi - Katedra Pedagogiki Społecznej i Pracy Socjalnej, Instytut Nauk Pedagogicznych, Wydział Filozofii i Nauk Społecznych; adres do korespondencji: ul. Lwowska 1, 87-100 Toruń, e-mail: tomrozan1@umk.pl; ORCID: https://orcid.org/0000-0003-3396-0916. 
i wsparcia społecznego, a także poszukiwania nowych rozwiązań $\mathrm{w}$ tym zakresie. Niezbędne jest również prowadzenie wieloaspektowych i systematycznych badań dotyczących tych kwestii.

W niniejszym artykule podjęto próbę odpowiedzi na następujące pytania: Co rozumie się przez starość oraz jakie są główne problemy i kryzysy ludzi starych? Jaka jest istota samotności i osamotnienia? Jakie są przyczyny, skutki, społeczne zróżnicowanie oraz sposoby przezwyciężania zjawiska samotności i osamotnienia osób starszych? Na czym polega rola edukacji w dziedzinie samotności i osamotnienia ludzi w starszym wieku?

\section{STAROŚĆ ORAZ GŁÓWNE PROBLEMY I KRYZYSY LUDZI STARSZYCH}

Ludzka starość, określana też m.in. późną dorosłością i wiekiem senioralnym (Steuden, 2011), stanowi przedmiot zainteresowania przedstawicieli wielu dyscyplin naukowych. Proponują oni różne sposoby definiowania tego pojęcia.

Zdaniem Jerzego Piotrowskiego, starość to „zjawisko kulturowe, wywołane na podłożu biologicznym, związane z osłabieniem sił, lecz jego wiązanie wyłącznie z wiekiem kalendarzowym jest umowne, wynikające z konwencji przyjętej w systemie zabezpieczeń społecznych" (cyt. za: Wawrzyniak, 2017b, s. 46). Natomiast według Adama A. Zycha, starość oznacza „nieunikniony efekt starzenia się, w którym procesy biologiczne, psychiczne i społeczne zaczynają oddziaływać względem siebie synergetycznie, prowadząc do naruszenia równowagi biologicznej i psychicznej bez możliwości przeciwdziałania temu" (Zych, 2001, s. 202).

Późna dorosłość stanowi zatem jeden z etapów życia człowieka, natomiast starzenie się ${ }^{1}$ - proces, jaki zachodzi w jego rozwoju. Jak podkreśla Zofia Szarota: „Starość [...] należy rozpatrywać w powiązaniu ze starzeniem się jako procesem, z jego demograficznymi, ekonomicznymi i społecznymi konsekwencjami, dostrzegając zarazem biologiczne i psychologiczne aspekty osobniczego starzenia się" (Szarota, 2004, s. 24).

\footnotetext{
${ }^{1}$ Starzenie się oznacza „stały, długotrwały proces fizjologiczny, który zachodzi w osobniczym rozwoju żywych organizmów" (Wawrzyniak, 2017b, s. 46). Zdaniem Stanisławy Steuden, starzenie się człowieka jest ,procesem przemian dokonujących się na poziomie biologicznym, psychicznym czy społecznym [...] ma wielorakie i złożone uwarunkowania genetyczne, biologiczne, środowiskowe i na poszczególnych etapach życia w zakresie różnych obszarów może ulegać przyspieszeniu lub zwolnieniu" (Steuden, 2011, s. 18-19).
} 
Dyscypliny naukowe, które zajmują się późną dorosłością, w różnoraki sposób określają jej początek oraz poszczególne fazy. Stąd wyróżnia się wiek: biologiczny, demograficzny, społeczny, psychiczny, ekonomiczny i socjalny (Szatur-Jaworska, 2006, s. 45). W naukach społecznych za początek omawianego okresu uznaje się zazwyczaj 60 bądź 65 rok życia (Brzezińska, 2011, s. 17). Zgodnie z klasyfikacją zaproponowaną przez ekspertów Światowej Organizacji Zdrowia, starość dzieli się na: wiek starzenia się tzw. wczesną starość (60-74 lat), wiek starczy - późną starość (75-89 lat) oraz wiek sędziwy - „długowieczność” (90 lat i więcej) (Chabior, 2017, s. 51-52).

W okresie starości dochodzi do kumulowania się różnych trudnych sytuacji życiowych. Obejmują one m.in.: problemy natury zdrowotnej, ekonomicznej, trudności związane z mieszkaniem, różnorakie problemy i troski rodzinne, trudności adaptacyjne, uzależnienia, problemy o charakterze emocjonalnym (Leszczyńska-Rejchert, 2016, s. 33-64). Niektóre zmiany zachodzące w fazie starości prowadzą do stanu, który w naukach psychologicznych nazywany jest kryzysem (Leszczyńska-Rejchert, 2016, s. 65). Kryzysy w późnej dorosłości zwykle wiążą się ze specyfiką zadań rozwojowych tego etapu życia i analizowane są często w kategoriach straty bądź kosztów starzenia się (Wawrzyniak, 2017b, s. 53). Do kluczowych zdarzeń krytycznych omawianego okresu zalicza się: przejście na emeryturę; opuszczenie domu rodzinnego przez ostatnie dziecko; wdowieństwo; pogarszanie się stanu zdrowia i kondycji fizycznej; utratę prestiżu społecznego; samotność i osamotnienie (zanikające więzi z bliskimi osobami, umieralność ludzi w podobnym wieku); zmianę miejsca zamieszkania (przeprowadzenie się do dzieci bądź do placówki opiekuńczej); świadomość zbliżającego się kresu życia (Szatur-Jaworska, 2000, s. 48; Straś-Romanowska, 2005, s. 267; Chabior, 2017, s. 67). Krytyczne zdarzenia w fazie późnej dorosłości stanowią dla człowieka wyzwanie - źródło nowych zadań (Wawrzyniak, 2017b, s. 60).

Podsumowując, należy stwierdzić, że starość, jako faza życia człowieka, powinna być rozpatrywana z uwzględnieniem różnorakich jej uwarunkowań oraz towarzyszących jej problemów i kryzysów. Stanowi ona rezultat długotrwałego i nieodwracalnego procesu, jakim jest starzenie się, i właśnie w powiązaniu z tym procesem powinna być analizowana. 


\section{SAMOTNOŚĆ, OSAMOTNIENIE - OKREŚLENIE POJĘĆ}

Istotnym problemem emocjonalnym i jednocześnie poważnym zagrożeniem egzystencjalnym dla wielu osób starszych jest samotność i osamotnienie. Badacze często podkreślają potrzebę rozróżnienia tych pojęć (Tokaj, 2008; Brzezińska, 2011; Czekanowski, 2017).

Zdaniem A.A. Zycha, samotność oznacza „obiektywny fakt bycia samym bądź życie w izolacji od innych osób, bez bliskich, rodziny, przyjaciół czy znajomych" (Zych, 2010, s. 155). Jak utrzymuje natomiast Stanisław Kawula: „Zjawisko samotności i osamotnienia ma swoje podłoże psychiczne i społeczne w zachowaniu jednostek. Samotność jest dolegliwym uwewnętrznionym stanem świadomości konkretnego człowieka, który przeżywa poczucie dystansu od innych ludzi i wynikającą z tego tęsknotę do zbliżenia się do wspólnot ludzkich, do relacji dających zadowolenie i nadających sens dalszemu życiu" (Kawula, 1999, s. 260). Samotność stanowi konsekwencję niezaspokojenia potrzeby intymności, a także następstwo niewystarczającego wzmocnienia społecznego (Kawula, 1999, s. 260).

Małgorzata Brzezińska zauważa, że samotność należy utożsamiać ze stanem obiektywnym, jaki charakteryzuje się brakiem kontaktów między ludźmi. Z kolei osamotnienie utożsamia się ze stanem subiektywnym, który wiąże się z cechami osobowości i wynika z poczucia braku bliskich więzi z innymi osobami oraz braku wspólnoty życia (Brzezińska, 2011, s. 54-55).

Podobnego rozróżnienia dokonuje Piotr Czekanowski. Jego zdaniem, „osamotnienie [...] wyraża subiektywne i przykre, psychiczne odczucia człowieka, związane z [...] utratą bądź brakiem istotnej osoby lub/i rzeczy, sytuacji czy wartości, które uzależnione są ponadto od stopnia indywidualnych oczekiwań w stosunku do tych osób, rzeczy, sytuacji i wartości" (Czekanowski, 2017, s. 247). Natomiast samotność uznaje on „za obiektywny, fizyczny stan jednostki, wskazujący na bycie (przebywanie) samemu ze względu na brak bezpośrednich kontaktów z innymi osobami" (Czekanowski, 2017, s. 247).

Jeszcze inny autor - Janusz Gajda - określa pojęcie samotności wyodrębniając trzy zasadnicze jej rodzaje: samotność społeczną, psychiczną i moralną (Gajda, 2006, s. 652-653). Pierwsza z nich dotyczy sytuacji, jaką cechuje osłabienie bądź brak więzi naturalnej z innymi osobami ( $\mathrm{tj}$. życie w luźnym związku ze społeczeństwem lub poza nim). Samotność psychiczna (osamotnienie) wiąże się ze sferą indywidualnych, subiektywnych odczuć człowieka, stanowi „stan braku więzi psychicznej - bliskiego kontaktu z drugim człowiekiem" (Gajda, 2006, s. 652). Samotność moralna związana jest 
z kolei z utratą (lub brakiem) ideałów i dążeń, jakie łączą się z systemem wartości. J. Gajda podaje, że: „Zintegrowany i realizowany system wartości pozwala przetrwać najtrudniejsze konflikty, znosić niepowodzenia i życiowe klęski, stanowi ratunek przed samotnością i ucieczkę od niej" (Gajda, 2006, s. 653).

Inny sposób interpretacji pojęcia samotności - istotny z pedagogicznego punktu widzenia - prezentuje Elżbieta Dubas (2000, s. 112-113). Wyróżnia ona samotność negatywną (złą) i pozytywną (dobrą). Najczęściej człowiek doświadcza tej pierwszej. W tym przypadku „mówi się o bólu i cierpieniu samotności, o wewnętrznym rozdarciu, doświadczeniu pustki, tęsknocie i nostalgii, smutku i zmartwieniu, goryczy, poczuciu niespełnienia, niepokoju, lęku i frustracji, niepewności, bezsilności [...]” (Dubas, 2000, s. 112). Samotność negatywna stanowi zatem ograniczenie rozwoju człowieka, zakłócenie jego normalnego funkcjonowania. Samotność pozytywną należy natomiast rozmieć jako sytuację, którą jednostka wybiera świadomie, „spostrzeganą jako dar, szansa rozwoju, zadanie rozwojowe, a nawet łaska. Samotność pozytywna [...] buduje osobowość, [...] pozwala na doświadczenie sensowności i radości życia" (Dubas, 2000, s. 113). Jak stwierdza E. Dubas: „Wydaje się, że istnieje możliwość, by złą samotność przekształcić w doświadczenie pozytywne. To przekształcenie wymaga często czasu na mentalną reorientację osobowości, ale jak się to wielokrotnie podkreśla, jest ono możliwe. I bywa wskazywane jako ważne zadanie wychowawcze" (tamże).

Analiza różnych definicji pozwala stwierdzić, że samotność rozumiana jest najczęściej jako stan obiektywny, cechujący się brakiem kontaktów międzyludzkich. $Z$ kolei osamotnienie utożsamia się zwykle ze stanem subiektywnym, wynikającym z poczucia braku bliskich więzi z drugim człowiekiem.

\section{SAMOTNOŚĆ I OSAMOTNIENIE OSÓB W STARSZYM WIEKU - ASPEKTY SPOŁECZNE I EDUKACYJNE}

Samotność i osamotnienie dotykają człowieka w różnych fazach jego życia. Problem ten dotyczy zarówno dzieci i młodzieży, jak i osób dorosłych, zwłaszcza ludzi starszych (Pawłowska, 2006). Szczególnie dokuczliwe jest poczucie osamotnienia (samotność psychiczna). Jak stwierdza Małgorzata Wałejko, niekiedy jest ono dla człowieka dramatem (Wałejko, 2016, s. 92). W istocie wiele badań i analiz odnosi się właśnie do tego zjawiska. Zdaniem S. Kawuli, do grup, które zagrożone są ryzykiem osamotnienia, 
zalicza się: ludzi mieszkających samotnie, osoby rozwiedzione i owdowiałe, rencistów, emerytów, bezrobotnych, ludzi ciężko chorych, osoby starsze (Kawula, 1999, s. 261).

$\mathrm{Z}$ analiz przeprowadzonych przez Joannę Wrótniak wynika, że aż $60 \%$ seniorów po 75 roku życia cierpi na osamotnienie. Co więcej, osamotnienie stanowi jedną z głównych przyczyn depresji u ludzi w starszym wieku. Ważną rolę $w$ życiu seniorów odgrywa nadal rodzina (stanowi ona istotne źródło wsparcia i kontaktów społecznych). Ludzie starzy - pomimo zaangażowania w życie rodzinne - często doświadczają osamotnienia, a ich pozycja w rodzinie obniża się (utrata pozycji uprzywilejowanej) (Wrótniak, 2015, s. 8182). Częstotliwość odczuwanego przez osoby starsze osamotnienia łączy się nie tylko z relacjami rodzinnymi, ale także z posiadaniem przyjaciół, co potwierdzają badania P. Czekanowskiego (Czekanowski, 2016, s. 223). Osamotnienie jest szczególnie silnie odczuwane przez ludzi starych, którzy zamieszkują w domach opieki (Szukalski, 2005, s. 236).

Zdaniem Pawła Kubickiego, w zależności od wyników zrealizowanych badań odsetek osamotnionych seniorów w Polsce (w wieku powyżej 65 roku życia) szacuje się „na poziomie od trochę poniżej jednej piątej populacji $16,6 \%[\ldots]$ do niecałej jednej trzeciej $29,4 \%$ [...]. Do najważniejszych czynników zwiększających ryzyko poczucia osamotnienia należy [zaliczyć przyp. autora] samodzielne zamieszkiwanie, płeć, wiek, stan cywilny i sytuację rodzinną (liczba dzieci i relacja z bliskimi), przy czym czynniki te są częściowo ze sobą powiązane, np. kobiety deklarują relatywnie częściej od mężczyzn odczuwanie osamotnienia także dlatego, że żyją dłużej od swoich partnerów i przez to częściej prowadzą jednoosobowe gospodarstwa domowe" (Kubicki, 2011, s. 70). Związek osamotnienia seniorów z cechami socjodemograficznymi (zwłaszcza takimi, jak wiek, płeć czy stan cywilny) potwierdzają wyniki wielu badań i analiz (Brzezińska, 2011; Czekanowski, 2012, 2016; Kliszcz, 2019).

Badania zrealizowane przez P. Kubickiego i M. Olcoń-Kubicką (na reprezentatywnej próbie polskich seniorów w wieku 65 lat i więcej) dowodzą, że ryzyko osamotnienia w większym stopniu dotyczy: kobiet, osób posiadających wykształcenie podstawowe i niższe, rencistów, mieszkańców wsi, mieszkańców wschodniego regionu Polski, a także osób ubogich i mieszkających samotnie. Ryzyko to w mniejszym stopniu odnosi się natomiast do: mężczyzn, osób posiadających wykształcenie zawodowe bądź wyższe, osób nadal aktywnych zawodowo, mieszkańców miast powyżej 500 tysięcy osób, seniorów niemieszkających samotnie (Kubicki, Olcoń-Kubicka, 2010, s. 132). 
Problem samotności senioralnej inaczej przedstawia się u kobiet, a inaczej u mężczyzn. Dla starszych kobiet utrata męża oznacza często poważny problem (szczególnie zaraz po śmierci małżonka). Jeśli jednak mają one rodzinę, to szybko włączają się w nurt życia rodzinnego oraz rozmaite prace i obowiązki na rzecz najbliższych. Kobiety owdowiałe mieszkające samotnie (bądź nieutrzymujące regularnych kontaktów z rodziną) zwykle dość dobrze potrafią przystosować się do nowej sytuacji (wykorzystując czas na zajęcia domowe bądź prace na rzecz innych osób). Inaczej wdowieństwo przedstawia się u mężczyzn, którzy stracili małżonkę w późnym wieku (Pędich, 1996, s. 25-26). Zazwyczaj jest tak, że „starzy wdowcy nie umieją przystosować się do samotności, tracą swoją pozycję w rodzinie [...]. Jeżeli mieszkają samotnie, mogą szybko ulec degradacji społecznej (osamotnienie, utrata kontaktów towarzyskich) oraz zdrowotnej (nieumiejętność przygotowania posiłków, zaniedbania żywieniowe, nasilenie niezaradności, pogorszenie zdrowia)" (Pędich, 1996, s. 26). Owdowiali mężczyźni wykazują mniejsze zdolności adaptacyjne aniżeli kobiety doświadczające wdowieństwa. Częściej cechuje ich brak chęci do podejmowania szerszej aktywności (Halicki, 2010, s. 92-93).

Grupę szczególnie zagrożoną samotnością stanowią seniorzy stanu wolnego, którzy nigdy nie pozostawali w związku małżeńskim. W okresie późniejszej starości ich dotychczasowe kontakty społeczne (rodzinne, zawodowe) zostają zwykle zerwane. Osoby te wymagają bardzo często pomocy ze strony rozmaitych instytucji (Pędich, 1996, s. 26).

Różnorakie są przyczyny samotności i osamotnienia osób w wieku senioralnym. Mogą być one analizowane na kilku płaszczyznach. W wymiarze społeczno-kulturowym samotności i osamotnieniu seniorów sprzyjają m.in. nasilone migracje, negatywne stereotypy dotyczące osób starszych (podkreślające ich bierną postawę życiową), zwiększający się dystans kulturowy między pokoleniami. W obszarze kontaktów społecznych istotne źródło osamotnienia stanowi izolacja społeczna ludzi starszych (wynikająca m.in. ze złej sytuacji materialnej, niskiego poziomu wykształcenia, śmierci współmałżonka czy zaawansowanego wieku) (Brzezińska, 2011, s. 55). Jak zauważa M. Brzezińska: „Na tym poziomie problem samotności i osamotnienia człowieka starszego wiąże się najmocniej z jego sytuacją rodzinną - powiązaniami między członkami rodziny, więziami emocjonalnymi, gotowością niesienia pomocy" (Brzezińska, 2011, s. 55). Potwierdzają to badania przeprowadzone przez E. Dubas, z których wynika, że udane życie rodzinne stanowi ważny czynnik chroniący przed osamotnieniem, natomiast problemy 
występujące w tym obszarze mogą potęgować poczucie odrzucenia (Dubas, 2000 , s. 494). W wymiarze indywidualnym przyczyny poczucia osamotnienia i samotności dzieli się na fizyczne i psychiczne. Pierwsze z nich obejmują przede wszystkim problemy natury zdrowotnej (np. skutkujące ograniczeniami w zakresie zdolności poruszania się). Przyczyny w sferze psychicznej wiążą się natomiast $\mathrm{z}$ określonymi cechami człowieka oraz dominującymi wzorcami zachowania (wskazuje się m.in. na związek poczucia osamotnienia z biernością, odczuwaniem nudy, ograniczonymi zainteresowaniami czy przejawianymi trudnościami $\mathrm{w}$ zakresie organizowania sobie czasu) (Brzezińska, 2011, s. 55).

Wyniki badań jakościowych, dotyczących brytyjskich seniorów - przeprowadzonych przez Christinę Victor i współpracowników (2004) - pokazują, że główne źródła poczucia osamotnienia (w opinii badanych) stanowią: ograniczenia sieci społecznych, w których uczestniczą seniorzy (np. na skutek śmierci współmałżonka, innych członków rodziny, przyjaciół); ograniczenia funkcjonalne i strukturalne (np. stan zdrowia utrudniający opuszczanie domu); ograniczenia osobowościowe danego człowieka (za: Szukalski, 2005, s. 235-236).

Doświadczanie samotności i osamotnienia może wywoływać niekorzystne skutki w różnych sferach funkcjonowania ludzi starych - psychicznej, społecznej, a niekiedy i somatycznej (Brzezińska, 2011, s. 56). Łączy się to $\mathrm{z}$ występowaniem negatywnych przeżyć (np. lęku, cierpienia, poczucia krzywdy, uczucia porażki, opuszczenia), brakiem aktywności i kontaktów społecznych, jak również pogarszającym się stanem zdrowia fizycznego (np. na skutek zaniedbań żywieniowych spowodowanych brakiem pomocy ze strony innych) (Leszczyńska-Rejchert, 2005, s. 105-106). Należy dodać, że samotność i osamotnienie mogą oddziaływać negatywnie na stosunek człowieka do samego siebie oraz własnej starości (Brzezińska, 2011, s. 56).

Samotność może nieść ze sobą także pozytywne skutki (Miszczak, 2007, s. 284). Bywa pożądana i świadomie wybierana (Steuden, 2011, s. 69). Jak zauważa Ewa Miszczak: „W sensie pozytywnym samotność może wyzwalać w człowieku niedostrzeżone dotychczas potencjały, może pomóc zrozumieć i poznać siebie samego. Samotność może być stanem wyciszenia, niezbędnego dla uporządkowania swoich spraw i problemów, może być oczyszczającą «pustynią»" (Miszczak, 2007, s. 284). Stanowi ona więc niekiedy pozytywne doświadczenie, nie zawsze musi współwystępować z poczuciem osamotnienia. Według Leona Dyczewskiego, w wieku senioralnym „samotność [...] może ułatwić człowiekowi prowadzenie najgłębszej refleksji nad 
swoim życiem, nad poszukiwaniem sensu swoich decyzji i działań, sensu własnego życia i świata" (Dyczewski, 2006, s. 115).

Rozmaite mogą być sposoby radzenia sobie z samotnością (osamotnieniem) w okresie starości. P. Czekanowski, na podstawie rezultatów swoich badań, wskazuje na trzy zasadnicze: sposób aktywno-indywidualny (np. spacery), pasywny (np. oglądanie telewizji) i towarzyski (np. spotkania z rodziną, w klubie seniora) (za: Dubas, 2000, s. 83). Z badań P. Kubickiego i M. Olcoń-Kubickiej wynika natomiast, że do rozwiązań nakierowanych na przezwyciężenie osamotnienia seniorzy zaliczają przede wszystkim: działalność uniwersytetów trzeciego wieku, klubów seniora oraz klubów czytelniczych (m.in. jako miejsc umożliwiających kontakt z rówieśnikami); akcje i imprezy adresowane do ludzi starszych; wyjazdy turystyczne, wycieczki; naukę obsługi komputera i narzędzi internetowych; wprowadzanie zmian ułatwiających osobom starszym funkcjonowanie w przestrzeni publicznej (Kubicki, Olcoń-Kubicka, 2010, s. 136).

Samotność (osamotnienie) najsilniej odczuwana jest przez osoby bierne (Wawrzyniak, 2017b, s. 57). Stąd w literaturze naukowej (zwłaszcza z zakresu gerontologii) podkreśla się potrzebę prowadzenia aktywnego życia w okresie późnej dorosłości (Dzięgielewska, 2006; Pikuła, 2011). Sposobem „przezwyciężania samotności jest kontynuowanie przez osoby w podeszłym wieku swojego czynnego życia na tyle, na ile pozwalają im ich możliwości [...]. Służy temu i sprzyja szeroko rozumiana aktywizacja ludzi starszych, prowadzona przez wyspecjalizowane placówki pomocy i opieki" (Wrótniak, 2015, s. 101). Aktywizację należy pojmować przede wszystkim jako pobudzanie, zachęcanie, motywowanie do działania, a także wskazywanie rozmaitych możliwości (Chabior, 2011, s. 65). W przypadku seniorów powinna ona polegać w szczególności na: stymulacji aktywności nierozbudzonej, wyzwalaniu aktywności stłumionej, modyfikowaniu aktywności niewłaściwie ukierunkowanej, zachęcaniu do poprawy własnego życia, zachęcaniu do poznawania i uczenia się nowych rzeczy, motywowaniu do współpracy z innymi (Wrótniak, 2015, s. 101). Aktywizacja może być realizowana $\mathrm{w}$ różnorakich formach. Ich wybór zależy w dużym stopniu od indywidualnych cech ludzi starszych, takich jak np. stan zdrowia, wykształcenie czy zainteresowania (Chabior, 2017, s. 65). Ważne jest „podejmowanie inicjatyw, dzięki którym seniorzy mogliby wykorzystywać swój potencjał, zaspokajać potrzebę bycia użytecznym, uznania" (Krzysztofiak, 2016, s. 238).

Aktywizacja może odnosić się do rozmaitych sfer życia osób starszych, m.in.: fizycznej (np. zajęcia ruchowe organizowane przez lokalne ośrodki 
sportu i rekreacji; zajęcia taneczne); społecznej (np. wolontariat; projekty międzypokoleniowe; spotkania odbywające się w klubach seniora); ekonomicznej (np. działania mające na celu przedłużanie aktywności zawodowej ludzi starszych; projekty przygotowujące do realizowania własnej działalności gospodarczej); intelektualnej (np. zajęcia organizowane przez uniwersytety trzeciego wieku; kluby dyskusyjne, filmowe, czytelnicze itp. prowadzone przez lokalne ośrodki kultury; spotkania tematyczne organizowane przez różne instytucje, np. dotyczące problematyki zdrowia, odżywiania) (Ziomek-Michalak, 2014, s. 73-76; Porąbaniec, 2016, s. 198-205; Wawrzyniak, 2017a, s. 237-239).

W procesie zapobiegania zjawiskom samotności i osamotnienia osób w starszym wieku szczególną rolę odgrywa aktywność edukacyjna, obejmująca zarówno uczenie się w wymiarze instytucjonalnym, jak i w codziennych sytuacjach życiowych (np. poprzez kontakty z innymi ludźmi czy korzystanie ze środków masowego przekazu). Zdaniem Olgi Czerniawskiej, niezbędna jest jednak aktywna postawa człowieka w stosunku do własnej osoby, jego chęć i gotowość do autoedukacji (Czerniawska, 2007, s. 438). Za istotne należy uznać więc kreowanie takiej przestrzeni edukacyjnej, która sprzyja kształtowaniu podmiotowości człowieka (Sokolnicka, 2009, s. 61-62).

Edukacja (nie tylko seniorów) w dziedzinie samotności i osamotnienia powinna obejmować przede wszystkim: kształtowanie zdolności do bycia samym (czy też umiejętności życia z samotnością); poznawanie sposobów (strategii) przezwyciężania osamotnienia ${ }^{2}$; uczenie się pozytywnego wykorzystywania sytuacji samotności (Leszczyńska-Rejchert, 2016, s. 62) jako szansy na rozwój oraz doświadczanie sensu i radości życia (Dubas, 2006, s. 347). W ramach działań edukacyjnych podejmowanych w tym obszarze uwzględnia się również: kształtowanie umiejętności nawiązywania relacji z innymi osobami; rozwijanie indywidualnych zainteresowań i upodobań; uczenie rozwiązywania problemów i pokonywania trudności życiowych (Dubas, 2000, s. 499). Edukacja w dziedzinie samotności i osamotnienia powinna zatem rozpoczynać się już we wczesnych etapach życia jako jedno

\footnotetext{
${ }^{2}$ Przekraczanie negatywnej samotności (osamotnienia) może dokonywać się w kilku zasadniczych relacjach: relacji ,ja-Bóg” (dążenie do zjednoczenia z Bogiem, przyjęcie wartości absolutnych), relacji ,ja-inni ludzie” (poszukiwanie innych ludzi, kontaktu z drugim człowiekiem), relacji ,ja-ja” (rozwijanie własnego świata wewnętrznego, umiejętności bycia z samym sobą), relacji ,ja-przyroda” (poszukiwanie kontaktów z naturą) (Dubas, 2006, s. 334-336). Zdaniem E. Dubas: „W życiu każdego człowieka przekraczanie samotności ma charakter zindywidualizowany, sytuacyjny, związany z poziomem osobowego rozwoju. Poszczególne sposoby przekraczania samotności często ze sobą współwystępują" (Dubas, 2006, s. 336).
} 
z działań przygotowujących człowieka do okresu późnej dorosłości i związanych z nim wyzwań (trudności, kryzysów). Obejmuje ona przekazywanie wiedzy, kształtowanie i rozwijanie umiejętności, formowanie postaw i przekonań. Niezwykle ważne w tym zakresie jest również jak najwcześniejsze zachęcanie i wdrażanie człowieka do samokształcenia ${ }^{3}$.

Edukacja osób starszych wpisuje się więc w ideę uczenia się całożyciowego (Konieczna, 2016, s. 52; Fabiś, 2017a, s. 171). W ramach strategii edukacyjnych wielu państw europejskich ,coraz wyraźniej rozwija się nurt profilaktyki gerontologicznej, stawiający sobie za cel główny przygotowanie do życia $\mathrm{w}$ starości oraz łagodzenie skutków osamotnienia przeżywanego często przez osoby «w wieku poprodukcyjnym». W Polsce profilaktyka ta nie osiągnęła jeszcze pełni rozwoju. Jest realizowana po pierwsze $\mathrm{z}$ dużym opóźnieniem w stosunku do prac podejmowanych w innych krajach, a po drugie w [...] ograniczonym zakresie" (Wrótniak, 2015, s. 102). Zasadnicze jej założenia znajdują swoje odzwierciedlenie m.in. w działalności uniwersytetów trzeciego wieku oraz klubów seniora. Pełny rozwój tej profilaktyki wymaga jednak realizacji przedsięwzięć, które będą miały zasięg ogólnospołeczny (np. wprowadzanie wiedzy gerontologicznej do programów szkolnych w szerszym wymiarze niż dotychczas, poszukiwanie nowych rozwiązań w zakresie pomocy i opieki środowiskowej) (Wrótniak, 2015, s. 102).

\section{ZAKOŃCZENIE}

Samotność i osamotnienie to zjawiska, których rozpatrywanie wymaga dokonania precyzyjnych ustaleń terminologicznych. Zjawiska te, przez niektórych badaczy analizowane wspólnie (chociaż nie zawsze współwystępują one ze sobą), mogą dotykać człowieka w różnych okresach jego życia. Nie są więc typowe tylko dla osób w starszym wieku. Liczne badania i analizy pokazują jednak, że samotność i osamotnienie w okresie starości to ważna i aktualna kwestia społeczna, która powinna być w większym stopniu dostrzegana i uwzględniana w społecznej polityce państwa (Szczupał, Wiśniewska, 2019).

\footnotetext{
${ }^{3}$ Chodzi w tym przypadku o dobrowolnie i samodzielnie podejmowany proces kształcenia się w rozmaitych dziedzinach nauki, sztuki, techniki i in. Ważną przestrzenią dla tak rozumianego samokształcenia powinien być czas wolny (Pięta, 2004, s. 112-113). Przygotowanie człowieka do racjonalnego sposobu wykorzystania czasu wolnego uznaje się za istotny element edukacji (wychowania) do starości (Kamiński, 1978).
} 
Omawiany problem pociąga za sobą potrzebę poszukiwania rozwiązań w zakresie opieki, pomocy i wsparcia społecznego. Nadal brakuje m.in. specjalistów udzielających pomocy/wsparcia samotnym i osamotnionym seniorom (Czekanowski, 2017). Niezwykle ważne jest również podejmowanie działań na rzecz integracji społeczności lokalnych (w tym integracji międzypokoleniowej) poprzez inicjowanie i wspieranie różnorakich przedsięwzięć, które sprzyjają aktywizacji seniorów oraz zwiększaniu ich udziału w życiu społecznym. Można wymienić wśród nich chociażby wolontariat, grupy samopomocowe czy formy zbiorowego spędzania czasu wolnego (Krzysztofiak, 2016; Zawada, 2017). Samotność i osamotnienie osób starszych to także istotny problem pedagogiczny, wymagający prowadzenia rzetelnych diagnoz oraz podejmowania zróżnicowanych działań edukacyjnych - skierowanych nie tylko do seniorów (z jednej strony mających na celu przeciwdziałanie osamotnieniu oraz ograniczanie jego skutków, z drugiej zaś - kształtujących przekonanie, że każdy ma prawo do samotności - tej pozytywnej, świadomie wybieranej, oraz przygotowujących do jej właściwego wykorzystywania). Konieczna jest wreszcie troska człowieka o własny rozwój - nie tylko w okresie późnej dorosłości, ale też we wcześniejszych fazach życia. Jak stwierdza Małgorzata Fopka-Kowalczyk: „Wydaje się, że w procesie wspierania osób starszych nie ma złotego środka. Oprócz bowiem oddziaływań osób zaangażowanych profesjonalnie istotne znaczenie ma również podejście do własnego starzenia się osoby starszej. Umiejętność znalezienia w sobie motywacji i chęci do aktywnego życia w podeszłym wieku pozwala przeżyć późniejszą dorosłość w poczuciu satysfakcji, świadomości samego siebie i zaspokajania psychicznych potrzeb, bez odczuwania alienacji czy odrzucenia" (Fopka-Kowalczyk, 2018, s. 79).

Podjęta w niniejszym artykule problematyka wymaga realizacji systematycznych badań. Dokonujące się współcześnie dynamiczne zmiany społeczne, ekonomiczne i kulturowe moga prowadzić bowiem do powstawania nowych źródeł samotności/osamotnienia człowieka, również w ostatniej fazie życia. Ponadto istotne wydaje się praktyczne wykorzystanie wyników badań dotyczących tego zagadnienia (Czekanowski, 2012, s. 140-142). Zdaniem P. Czekanowskiego, „część prowadzonych badań mogłaby posłużyć jako punkt wyjścia do dalszych działań, których efektem stawałyby się konkretne propozycje realnych rozwiązań" (Czekanowski, 2012, s. 141). 


\section{BIBLIOGRAFIA}

BrZeziŃSKA, M. (2011). Proaktywna starość. Strategie radzenia sobie ze stresem w okresie późnej dorosłości. Warszawa: Difin SA.

CHABIOR, A. (2011). Aktywizacja i aktywność ludzi w okresie późnej dorosłości. Kielce: Wszechnica Świętokrzyska.

CHABIOR, A. (2017). Wspomaganie procesu pomyślnego starzenia się u ludzi starych. Między powinnościa a profesją. Kraków: Oficyna Wydawnicza „Impuls”.

Czekanowski, P. (2012). Społeczne aspekty starzenia się ludności w Polsce. Perspektywa socjologii starości. Gdańsk: Wydawnictwo Uniwersytetu Gdańskiego.

CzeKanowski, P. (2016). Osamotnienie starych mieszkańców Gdańska - kwestie metodyczne oraz zaistniałe zróżnicowania. W: M. Halicka, J. HALicki, E. KramkowsKa (red.), Starość. Poznać, przeżyć, zrozumieć (s. 213-227). Białystok: Wydawnictwo Uniwersytetu w Białymstoku.

CZeKanowski, P.A. (2017). Samotność i osamotnienie w okresie starości. W: A.A. ZYCH (red.), Encyklopedia starości, starzenia się i niepetnosprawności, t. 3 (s. 246-249). Katowice: Stowarzyszenie Thesaurus Silesiae - Skarb Śląski.

CZERniawSKa, O. (2007). Edukacja jako pomoc w rozwoju w ujęciu andragogiki i gerontologii. W: E. Marynowicz-HetKa (red.), Pedagogika społeczna. Podręcznik akademicki. Debata, t. 2 (s. 433-443). Warszawa: Wydawnictwo Naukowe PWN.

DuBAs, E. (2000). Edukacja dorostych w sytuacji samotności i osamotnienia. Łódź: Wydawnictwo Uniwersytetu Łódzkiego.

DubAs, E. (2006). Samotność - uniwersalny „temat” życia ludzkiego i wychowania. W: P. DoMERACKI, W. TYBURSKI (red.), Zrozumieć samotność. Studium interdyscyplinarne (s. 329-349). Toruń: Wydawnictwo Uniwersytetu Mikołaja Kopernika.

Dyczewski, L. (2006). Wartości w życiu człowieka starego. W: M. HALICKA, J. HALICKi (red.), Zostawić ślad na ziemi. Księga pamiątkowa dedykowana Profesorowi Wojciechowi Pędichowi $w 80$ rocznice urodzin i 55 rocznice pracy naukowej (s. 113-119). Białystok: Wydawnictwo Uniwersytetu w Białymstoku.

DZIĘGIELEWSKA, M. (2006). Aktywność społeczna i edukacyjna na tle innych typów aktywności. W: B. Szatur-Jaworska, P. BŁędowski, M. DzięGielewska, Podstawy gerontologii spotecznej (s. 161-165). Warszawa: Oficyna Wydawnicza ASPRA-JR.

FABIŚ, A. (2017a). Edukacja osób starszych. W: A. FABIŚ, J.K. WAWRZYNIAK, A. CHABIOR, Ludzka starość. Wybrane zagadnienia gerontologii społecznej (s. 171-198). Kraków: Oficyna Wydawnicza „Impuls”.

FABIŚ, A. (2017b). Troski i niepokoje egzystencjalne ludzi dojrzałych. W: A. FABIŚ, J.K. WAWRZYNIAK, A. CHABIOR, Ludzka starość. Wybrane zagadnienia gerontologii społecznej (s. 279297). Kraków: Oficyna Wydawnicza „Impuls”.

Fabiś, A., Wawrzyniak, J.K., Chabior, A. (2017). Wstęp. W: A. Fabiś, J.K. WawrzyniaK, A. CHABIOR, Ludzka starość. Wybrane zagadnienia gerontologii społecznej (s. 9-12). Kraków: Oficyna Wydawnicza „Impuls”.

FOPKA-KowALCZYK, M. (2018). Samotność osób starszych i czynniki ją warunkujące. Kultura i Edukacja, 1(119), 70-80.

GajdA, J. (2006). Samotność. W: T. PILch (red.), Encyklopedia pedagogiczna XXI wieku, t. 5 (s. 652-657). Warszawa: Wydawnictwo Akademickie „Żak”. 
HALICKI, J. (2010). Obrazy starości rysowane przeżyciami seniorów. Białystok: Wydawnictwo Uniwersytetu w Białymstoku.

KAMIŃSKI, A. (1978). Wychowanie do starości jako czynnik adaptacji ludzi starszych do nowoczesnego społeczeństwa. W: A. KAMiński, Studia i szkice pedagogiczne (s. 356-391). Warszawa: Państwowe Wydawnictwo Naukowe.

KANIOS, A. (2018). Postawy pracowników zawodów pomocowych wobec osób starszych. Lublin: Wydawnictwo Uniwersytetu Marii Curie-Skłodowskiej.

Kawula, S. (1999). Samotność. W: D. LALAK, T. PILCH (red.), Elementarne pojęcia pedagogiki społecznej i pracy socjalnej (s. 260-262). Warszawa: Wydawnictwo Akademickie „Żak”.

KLiszcz, J. (2019). Psychologia potrzeb osób starszych. Potrzeby psychospołeczne po 65. roku życia. Warszawa: Difin SA.

Konieczna, E. (2016). Seniorzy i film. Aktywizacja i integracja społeczna osób starszych przez uczestnictwo w kulturze filmowej. Torun: Wydawnictwo Adam Marszałek.

KRAMKOWSKA, E. (2016). Człowiek stary jako ofiara przemocy w rodzinie. Gdańsk: Wydawnictwo Naukowe Katedra-Białystok: Wydział Pedagogiki i Psychologii Uniwersytetu w Białymstoku.

KRZYSZTOFIAK, D. (2016). Oblicza starości w perspektywie lokalnej. Studium socjopedagogiczne. Kraków: Oficyna Wydawnicza „Impuls”.

KUBICKI, P. (2011). Starość i życie codzienne osamotnionych seniorów. W: J. Mucha, Ł. KRZYżOWSKI (red.), Ku socjologii starości. Starzenie się w biegu życia jednostki (s. 69-82). Kraków: Wydawnictwa AGH.

Kubicki, P., OlcoŃ-Kubicka M. (2010). Osamotnienie osób starszych w Polsce - skala, przejawy oraz sposoby przeciwdziałania zjawisku. Studia Humanistyczne AGH, 8, 129-138.

LESZCZYŃSKA-REJCHERT, A. (2005). Człowiek starszy i jego wspomaganie - w strone pedagogiki starości. Olsztyn: Wydawnictwo Uniwersytetu Warmińsko-Mazurskiego.

LESZCZYŃSKA-REJCHERT, A. (2016). Praca socjalna z seniorami $w$ perspektywie geragogiki. Olsztyn: Wydawnictwo Uniwersytetu Warmińsko-Mazurskiego.

MiszczaK, E. (2007). Problem samotności i osamotnienia ludzi starszych w Polsce. W: B. BUGAJSKA (red.), Życie w starości (s. 279-286). Szczecin: ZAPOL.

PAWŁowsKa, R. (2006). Samotność człowieka - rozważania teoretyczne. W: R. PAwŁowskA, E. JundZıŁŁ, Pedagogika człowieka samotnego (s. 17-44). Gdańsk: Gdańska Wyższa Szkoła Humanistyczna.

PĘDich, W. (1996). Ludzie starzy. Warszawa: Centrum Rozwoju Służb Społecznych.

PIĘTA, J. (2004). Pedagogika czasu wolnego. Warszawa: Wyższa Szkoła Ekonomiczna.

PIKUŁA, N. (2011). Etos starości w aspekcie społecznym. Gerontologia dla pracowników socjalnych. Kraków: Wyższa Szkoła Filozoficzno-Pedagogiczna Ignatianum, Wydawnictwo WAM.

PORĄBANIEC, M. (2016). Działalność aktywizacyjna osób starszych w środowisku lokalnym. W: M. Duda, K. KuteK-SŁadeK (red.), Eliminacja wykluczenia spolecznego (s. 187-207). Kraków: Uniwersytet Papieski Jana Pawła II w Krakowie.

Rembowski, J. (1992). Samotność. Gdańsk: Uniwersytet Gdański.

SokolnickA, A. (2009). Edukacja jako przestrzeń rozwoju podmiotowości jednostki. Paedagogia Christiana, 1(23), 53-62.

Steuden, S. (2011). Psychologia starzenia się i starości. Warszawa: Wydawnictwo Naukowe PWN. 
StraŚ-Romanowska, M. (2005). Późna dorosłość. Wiek starzenia się. W: B. HarWAS-NAPIERala, J. Trempala (red.), Psychologia rozwoju czlowieka. Charakterystyka okresów życia człowieka (s. 263-292). Warszawa: Wydawnictwo Naukowe PWN.

Szarota, Z. (2004). Gerontologia społeczna i oświatowa. Zarys problematyki. Kraków: Wydawnictwo Naukowe Akademii Pedagogicznej im. Komisji Edukacji Narodowej.

SzATUR-JAWORSKA, B. (2000). Ludzie starzy i starość w polityce spolecznej. Warszawa: Instytut Polityki Społecznej Uniwersytetu Warszawskiego.

Szatur-Jaworska, B. (2006). Starość - opis fazy. W: B. Szatur-JaworsKa, P. BłęDowski, M. DzIĘGIelewsKa, Podstawy gerontologii spolecznej (s. 45-58). Warszawa: Oficyna Wydawnicza ASPRA-JR.

SzCZUPAŁ, B., WiŚNIEWSKA, J.I (2019). Samotność i poczucie osamotnienia w narracji osób w wieku późnej starości - przejawy oraz możliwości przeciwdziałania. Lubelski Rocznik Pedagogiczny, 4(38), 25-40, https://journals.umcs.pl/lrp/article/view/9929/7379 (dostęp: 14.04.2020).

SzUKALSKI, P. (2005). Poczucie samotności i osamotnienia wśród sędziwych seniorów a ich sytuacja rodzinna. Auxilium Sociale, 2(34), 217-238.

TOKAJ, A. (2008). Krótka refleksja nad samotną i osamotnioną starością. W: R. KonIECZNA-WoźNIAK (red.), Dorostość wobec starości. Oczekiwania - Radości - Dylematy (s. 219-226). Poznań: Wydawnictwo Naukowe UAM.

WaŁejko, M. (2016). Osobno i razem. Personalistyczne wychowanie do samotności i wspólnoty. Szczecin: Uniwersytet Szczeciński.

WAWRZYNIAK, J.K. (2017a). Aktywność zawodowa seniorów. W: A. FABIŚ, J.K. WAWRZYNIAK, A. CHABIOR, Ludzka starość. Wybrane zagadnienia gerontologii społecznej (s. 222-239). Kraków: Oficyna Wydawnicza „Impuls”.

WAWRZYNiAK, J.K. (2017b). Starzenie się i jego charakterystyka. W: A. FABIŚ, J.K. WAWRZYNIAK, A. CHABIOR, Ludzka starość. Wybrane zagadnienia gerontologii spotecznej (s. 42-78). Kraków: Oficyna Wydawnicza „Impuls”.

WRÓTNIAK, J. (2015). Zasoby psychospołeczne osób w podeszlym wieku z poczuciem samotności. Lublin: Wydawnictwo Uniwersytetu Marii Curie-Skłodowskiej.

ZAWADA, A. (2017). Ubóstwo i wykluczenie społeczne osób w podeszłym wieku. W: A.A. ZYCH (red.), Encyklopedia starości, starzenia się i niepetnosprawności, t. 4 (s. 103-107). Katowice: Stowarzyszenie Thesaurus Silesiae - Skarb Śląski.

ZiomeK-MichalaK, K. (2014). Wykorzystanie potencjału środowiska lokalnego w pracy z osobami starszymi. W: M. MiкOŁAJCZYK (red.), Pomoc społeczna i praca socjalna - różne oblicza i zadania (s. 70-83). Warszawa: Wydawnictwo APS

ZYCH, A.A. (2001). Stownik gerontologii spolecznej. Warszawa: Wydawnictwo Akademickie „Żak”.

ZYCH, A.A. (2010). Leksykon gerontologii. Kraków: Oficyna Wydawnicza „Impuls”.

\section{SAMOTNOŚĆ I OSAMOTNIENIE OSÓB STARSZYCH JAKO PROBLEM SPOŁECZNY I EDUKACYJNY}

\section{STRESZCZENIE}

Artykuł poświęcono społecznym i edukacyjnym aspektom samotności i osamotnienia osób starszych. Punktem wyjścia podjętych rozważań było określenie pojęcia starości oraz wskazanie 
głównych problemów i kryzysów ludzi starych. W dalszej kolejności wyjaśniono istotę samotności i osamotnienia. Następnie, odwołując się do wyników wybranych badań i analiz, omówiono problem samotności i osamotnienia osób starszych. Wskazano na społeczne zróżnicowanie, przyczyny oraz skutki rozpatrywanych zjawisk, a także sposoby ich przezwyciężania. Zwrócono również uwagę na rolę edukacji w dziedzinie samotności i osamotnienia osób w wieku senioralnym.

Słowa kluczowe: edukacja; osamotnienie; samotność; osoba starsza; starość.

\section{LONELINESS AND SOLITUDE OF THE ELDERLY AS A SOCIAL AND EDUCATIONAL PROBLEM}

SUMMARY

The article is devoted to the social and educational aspects of loneliness and solitude of the elderly. The starting point of the considerations was to define the concept of old age and to indicate the main problems and crises of old people. Next, the essence of loneliness and solitude was explained. Then, referring to the results of selected studies and analyses, the problem of loneliness and solitude of the elderly was discussed. The social diversity and causes and effects of the considered phenomena, as well as ways of overcoming them, were pointed out. Attention was also paid to the role of education in the field of loneliness and solitude of senior citizens.

Keywords: education; solitude; loneliness; elderly person; old age. 